ACTA UNIVERSITATIS WRATISLAVIENSIS No 3928

Slavica Wratislaviensia CLXXI • Wrocław 2020

DOI: $10.19195 / 0137-1150.171 .4$

Data przesłania artykułu: 24.10 .2018

Data akceptacji artykułu: 16.04.2019

JOLANTA LUBOCHA-KRUGLIK

Uniwersytet Śląski w Katowicach, Polska

\title{
Leksyka specjalistyczna w tekście literackim a kompetencje tłumacza (na materiale polskich przekładów powieści kryminalnych Aleksandry Marininy)
}

W niniejszym artykule interesować nas będą kompetencje tłumacza postrzegane w kontekście oceny ,produktu” powstałego w wyniku jego działania. Ocena ta będzie dotyczyć komponentów wiedzy thumaczeniowej, między innymi znajomości przedmiotu thumaczenia, „wiedzy o świecie” i wiedzy specjalistycznej, a także określonych sprawności, jak na przykład umiejętności profesjonalnego przekodowania komunikatu. Rozważania prowadzone będą na podstawie analizy tłumaczeń powieści kryminalnych rosyjskiej pisarki Aleksandry Marininy.

Kompetencje thumacza to dziś jeden z modnych tematów badań naukowych. Mimo jednak wielu opracowań teoretycznych na ten temat model tych kompetencji nie został jeszcze ustalony w ostatecznym kształcie, stopień zaś jego złożoności stale się zwiększa. Zakłada się zwykle, że na kompetencje podstawowe thumacza składa się wiele subkompetencji, obejmujących między innymi takie sprawności, jak komunikacyjna i tekstowa w co najmniej dwóch językach; tematyczna w dziedzinach, w których tłumacz wykonuje tłumaczenie; umiejętność poszukiwania danych i właściwego ich wykorzystania. Poza obszarem mojego zainteresowania pozostają inne umiejętności, takie jak na przykład obsługa programów wspomagających pracę thumacza, obsługa urządzeń informatycznych, umiejętności techniczne, takie jak prowadzenie biura ${ }^{1}$, czy umiejętności w zakresie promocji. Nie jest bowiem moim celem wskazanie na wszystkie kompetencje, jakie powinien

${ }^{1}$ Zob. J. Albin, Kompetencja z punktu widzenia thumacza, [w:] Kompetencje thumacza, red. M. Piotrowska et al., Kraków 2012, s. 33. W artykule tym autorka omawia szczegółowo hierarchiczny model kompetencji thumaczeniowych opracowany przez Dorothy Kelly. 
posiąść tłumacz, lecz jedynie zasygnalizowanie, jakie są dziś oczekiwania wobec tłumacza tekstów literackich, w których występuje leksyka specjalistyczna.

Urszula Dąmbska-Prokop wskazuje, że ,na kompetencję tłumaczeniową składają się w istocie kompetencja językowa, kompetencja kulturowa + kompetencja encyklopedyczna (wiedza), kompetencja psychologiczna i logiczna, i wreszcie kompetencja pragmatyczna"2. Podstawową kompetencją thumacza jest bez wątpienia kompetencja językowa w zakresie obu języków, którymi tłumacz się posługuje. Na ten rodzaj kompetencji składa się „kompetencja leksykalna, składniowa, prozodyczna, stylistyczna (znajomość różnych rejestrów języka) i dyskursywna (znajomość reguł charakterystycznych dla takiego czy innego dyskursu) [...], umiejętność odróżnienia pewnych form dialektowych, żargonowych, archaicz-

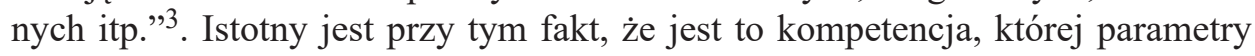
ciągle się zmieniają, na przykład w wyniku wzbogacenia systemu leksykalnego tłumacza lub zapominania pewnych pojęć.

Franciszek Grucza zaś wprowadził pojęcie „kompetencja translatoryczna”,

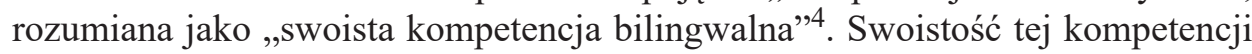
polega na tym, że właściwości translatoryczne tworzą nadbudowę, uwarunkowaną sprawnościami językowymi, ale nie wynikającą z nich automatycznie. Kompetencja tłumaczeniowa to pewna wiedza, umiejętności i zdolności tłumacza, zarówno nabywane w procesie akwizycji języka (nieświadome), jak i świadomie rozwijane w procesie kształcenia ${ }^{5}$.

Zauważmy przy tym, że proponowane modele kompetencji thumaczeniowej starają się zachować wymiar ogólny, bez szczegółowego odniesienia się do kompetencji tłumaczy literackich czy specjalistycznych, choć wymagany czy też pożądany zakres umiejętności może wydawać się zupełnie różny. Zakładają one, że powinien je mieć każdy tłumacz w stopniu wystarczającym do prawidłowego wykonania przydzielonych mu zadań. Harmonijne połączenie poszczególnych kompetencji powinno, przynajmniej teoretycznie, skutkować przekładem, który można uznać za wolny od błędów.

W czasach jeszcze nie tak odległych w badaniach przekładoznawczych panowała dychotomia art vs craft. Na tej podstawie wyraźnie oddzielało się kompetencje tłumacza literackiego od tłumacza tekstów nieliterackich. Halina Dzierżanowska już prawie trzydzieści lat temu w monografii Przekład tekstów nieliterackich na przykładzie języka angielskiego pisała, że „,praca nad przekładem staje

${ }^{2}$ U. Dąmbska-Prokop, Kompetencje thumacza, [w:] Mała encyklopedia przekładoznawstwa, red. U. Dąmbska-Prokop, Częstochowa 2000, s. 109.

${ }^{3}$ A. Pisarska, T. Tomaszkiewicz, Wspótczesne tendencje przekładoznawcze, Poznań 1996, s. 68.

${ }^{4}$ F. Grucza, Zagadnienia translatoryki, [w:] Glottodydaktyka a translatoryka, red. F. Grucza, Warszawa 1981, s. 9-27; idem, Lingwistyka, lingwistyka stosowana, glottodydaktyka, translatoryka, Poznań 1996, s. 68.

${ }^{5}$ F. Grucza, Lingwistyka, lingwistyka stosowana, glottodydaktyka, translatoryka, [w:] Lingwistyka, glottodydaktyka, translatoryka, red. F. Grucza, Warszawa 1985, s. 19-44. 
się czynnością zbliżoną do odczytywania zaszyfrowanych informacji”' . Po latach można stwierdzić, że proces ten nie tylko nie stał się łatwiejszy, lecz problemy $z$ dekodowaniem informacji mogą być nawet większe. Instrumentarium współczesnego thumacza jest $\mathrm{z}$ pewnością bogatsze, łatwiejszy jest dostęp do źródeł, dzięki którym można weryfikować swą wiedzę i dokonane wybory translatorskie (na przykład korpusy równoległe, teksty paralelne), jednak przed tłumaczami objawiają się nowe wyzwania, którym nie zawsze są oni w stanie sprostać. Należy do nich zetknięcie się $\mathrm{w}$ trakcie pracy nad tekstem $\mathrm{z}$ wymieszaniem form dyskursu, z syntezą różnych gatunków.

Zauważmy, że w polskich badaniach przekładoznawczych o orientacji literackiej mówi się o strategiach thumaczeniowych w odniesieniu do konkretnych przypadków przekładu literackiego (na przykład transformacje kulturowe, estetyczne i leksykalno-semantyczne w przekładzie baśni, strategie thumaczenia literatury dziecięcej, strategie thumaczenia poezji konkretnego autora). Nie ma w nich jednak mowy chociażby o strategii thumaczenia takich tekstów, o których mowa w niniejszym artykule, a przecież są to teksty dość szczególne. Nie sposób bowiem nie dostrzec zmian zachodzących w dziedzinie powieści kryminalnej, której efektem jest rosnąca liczba genologicznych etykiet towarzyszących publikacji coraz to nowych książek kojarzonych z tym gatunkiem. Być może rzeczywiście jest tak, jak twierdzi Maria Piotrowska: „Współczesne przekładoznawstwo europejskie nie skłania się ku podziałom opartym na typach tekstów, a szczególnie na rozróżnieniu literackości-nieliterackości"7. Do strategii przekładowych odnosi się też Edward Balcerzan, przedstawiając propozycję, którą nazywa „instrukcją strategiczną" i uważa za niezbędną w warsztacie każdego tłumacza. „Instrukcja strategiczna” nie może być algorytmicznym spisem poleceń, których wykonanie gwarantuje sukces przekładowy, może natomiast tworzyć wytyczną ${ }^{8}$. Ta postulowana strategiczność przekładu pozwala na wypracowanie podejścia umożliwiającego zastosowanie pewnych procedur, których celem jest skuteczność kontekstowa.

W dzisiejszych czasach często wypowiadane zdanie: „Tłumaczenie jest procesem złożonym" należy traktować już chyba wyłącznie jako truizm. Złożoność tego procesu jest bowiem oczywista, jednak takie postawienie sprawy pozwala na usprawiedliwienie pewnych potknięć, uproszczeń czy nawet na pomijanie spraw trudnych.

Przedmiotem analizy w niniejszym artykule będą wybrane aspekty przekładu powieści kryminalnych rosyjskiej pisarki Aleksandry Marininy9 ${ }^{9}$ Są one przykładem znakomitego rzemiosła, popartego dużym talentem literackim przy

${ }^{6}$ H. Dzierżanowska, Przekład tekstów nieliterackich na przykładzie języka angielskiego, Warszawa 1990, s. 13.

${ }^{7}$ M. Piotrowska, Proces decyzyjny tlumacza. Podstawy metodologii nauczania przekładu pisemnego, Kraków 2007, s. 70.

${ }^{8}$ E. Balcerzan, Literatura z literatury (strategie tlumaczy), Katowice 1998, s. 192.

${ }^{9}$ Cały cykl obejmuje obecnie 46 pozycji (dane ze strony www.marinina.ru [dostęp: 1.10.2017]). $\mathrm{Na}$ język polski przetłumaczono dotychczas 20 . Wszystkie powieści tłumaczone były przez kobiety: 
jednoczesnej doskonale opanowanej umiejętności kreowania intrygi kryminalnej. Zalicza się je zwykle do powieści milicyjnych, choć w niczym nie przypominają tych, nad którymi pastwił się ironicznie Stanisław Barańczak w Ksiązkach najgorszych. Posługując się terminem Mariusza Czubaja, można powiedzieć raczej, że reprezentują one gatunek „zmącony”, są bowiem ,jeszcze jednym świadectwem zasadniczej zmiany w kulturze współczesnej, której efektem jest wymieszanie się form dyskursu" ${ }^{10}$. Powieść kryminalna w mniejszym stopniu niż kiedyś jest łamigłówką intelektualną, niekoniecznie też (jak kiedyś u Chandlera) dotyczy mechanizmów rozprzężenia społecznego i zacierania się granic między dobrem a złem. W powieściach Marininy nie leje się krew, nie ma brutalnych opisów, fałszywych tropów czy sensacyjnego pościgu. Autorka rekompensuje to czytelnikom, wplatając w swe książki wątki psychologiczne i obyczajowe. Większą uwagę zwraca na motyw sprawcy niż na samo popełnione przez niego przestępstwo. Marinina zna doskonale środowisko przestępcze oraz tok myślenia kryminalistów, dzięki czemu może przewidzieć ich poczynania. Ponadprzeciętne umiejętności zaś sprawiają, że potrafi w mistrzowski sposób je opisać. Nie ulega też wątpliwości, że w wykreowaniu bohaterki (później zaś bohaterów) swoich powieści, które tak bardzo przypadły do serca jej czytelnikom, pomaga Marininie jej zawodowe doświadczenie. Po ukończeniu wydziału prawa na Moskiewskim Uniwersytecie Państwowym w 1979 roku Marinina została skierowana do Akademii Ministerstwa Spraw Wewnętrznych. W latach 1979-1998 pracowała w milicji, zajmując się działalnością edukacyjną i pracami badawczymi w dziedzinie kryminologii. W 1980 roku została pracownikiem naukowym w stopniu lejtnanta (podporucznika) milicji. Zajmowała się analizą osobowości przestępcy z anomaliami psychiki, a także przestępców popełniających przestępstwa $\mathrm{z}$ użyciem siły w warunkach recydywy. W 1986 roku obroniła pracę doktorską Личность осужденного за насильственные преступления и предупреждение специильного реиидива. Od 1987 roku zajmowała się badaniem i prognozowaniem przestępczości. Jest autorką ponad 30 prac naukowych, w tym monografii Crime and Crime Prevention in Moscow, wydanej przez Międzyregionalny Instytut ONZ ds. Badań nad Przestępczością i Wymiarem Sprawiedliwości (UNICRI).

W 1998 roku odeszła z milicji w stopniu podpułkownika i rozpoczęła działalność literacką. W 1991 roku opowiadanie kryminalne Шестикрылый Серафим, napisane wspólnie z Aleksandrem Gorkim, zostało opublikowane w magazynie „Милиция”. W 1993 roku ukazała się jej pierwsza powieść Стечение обстоятельств ${ }^{11}$ (dosł. Zbieg okoliczności; polski przekład - Kolacja z zabójcą ${ }^{12}$ ) z cyklu, którego bohaterką jest major Anastazja Kamieńska.

pierwszą przetłumaczyła Margarita Bartosik w 2007 roku, następne — Ewa Rojewska-Olejarczuk 2, Aleksandra Stronka - 14, Elżbieta Rawska - 3.

${ }^{10}$ M. Czubaj, Etnolog w mieście grzechu. Powiessć kryminalna jako świadectwo antropologiczne, Gdańsk 2010, s. 28.

${ }^{11}$ A. Marinina, Stečenie obstoâtel'stv, Moskva 1993.

12 A. Marinina, Kolacja z zabójca, przeł. M. Bartosik, Warszawa 2010. 
W polskich przekładach powieści Marininy na ogół nie obserwujemy odejścia od oryginału pod względem cech strukturalnych — niewiele więc jest tu opuszczeń, dodań lub substytucji. Jeśli zaś takie transformacje w tekście występują, to wynikają one zazwyczaj z różnic systemowych między oboma językami i są to działania w obrębie struktury słowa, grupy słownej lub zdania. Uwagę zwracają za to pewne rozwiązania na płaszczyźnie kulturowo-pragmatycznej, cechujące się tendencją do egzotyzacji tekstu, do aktywizowania w nim kategorii obcości. W charakterze sygnałów obcości w przekładach powieści rosyjskich występują najczęściej imiona własne i patronimiki, jednak pozostają tu one poza głównym nurtem badań.

W tekstach Marininy nie ma metafizyki, nie ma wyszukanych metafor czy zaskakujących porównań. Na kartach książek pisarki spotykamy jednak bardzo poprawny język literacki, język potoczny, a także zaawansowany język specjalistyczny, zarówno medyczny, jak i prawniczy czy policyjny. Ta mieszanina powoduje, że lekkość stylu Marininy nie zawsze znajduje odzwierciedlenie w przekładzie. To, co dla Marininy jest naturalne, czyli przełączanie się z jednej odmiany języka na drugą, dla thumaczek stanowi pewne wyzwanie. Problemy pojawiają się też w przekładzie konkretnych terminów z zakresu prawa i praktyki dochodzeniowo-śledczej. Wyjaśnienie tych problemów wydaje się dość proste. Tłumacz tekstów literackich, a do takich przecież należą powieści Marininy, zwykle nie ma odpowiedniego przygotowania specjalistycznego. Zmącenie gatunku powoduje więc określone problemy.

Prześledźmy to na wybranych przykładach. W wielu miejscach tekstu obserwujemy niekompetencję tłumaczek wynikającą z niedostatecznej znajomości odpowiedniej terminologii. Jako przykład może tu posłużyć termin предварительное расследование, który w polskim przekładzie występuje jako śledztwo wstępne. Jest to termin, który pojawia się już w pierwszym przekładzie autorstwa Margarity Bartosik i jest powielany w kolejnych thumaczeniach. Termin zastosowany przez tłumaczkę jest przykładem tłumaczenia dosłownego. Nie ma żadnego uzasadnienia do wprowadzania go do tekstu, albowiem w polskim prawie karnym jego właściwym odpowiednikiem jest postępowanie przygotowawcze.

Dużym problemem dla tłumaczek są też abrewiatury, a dokładniej — ich prawidłowe odczytanie. Przykładem tego może być tłumaczenie zaproponowane przez Bartosik w Kolacji z zabójca (Стечение обстоятельств). Tłumaczka nieprawidłowo rozszyfrowała abrewiaturę w komentarzu, czego konsekwencją jest wprowadzenie do obiegu nieistniejącego bytu. Chodzi tu o skrót MYP, który tłumaczka błędnie rozszyfrowała jako Московское управление розыска. Komentarz tłumaczki: Московское управление розыска - MUR Moskiewski Urząd Śledczy. МУP to jednak Московский уголовный розыск, а więc Wydziat Kryminalny Moskwy (Moskiewski Wydział Kryminalny). Ekwiwalent zaproponowany przez tłumaczkę można sklasyfikować jako błąd wynikający z braku wiedzy ogólnej i specjalistycznej. W tekście tłumaczka używa ponadto abrewiatury, która 
ze względu na błąd merytoryczny w komentarzu jest dla polskiego czytelnika kompletnie niezrozumiała.

Когда он возглавил отдел в МУРе, работа под его руководством пошла куда успешнее. (Стечение обстоятельств, s. 21)

Kiedy staną na czele wydziału MUR-u, wyniki pod jego kierownictwem wyraźnie się poprawity. (Kolacja z zabójca, s. 18)

Z punktu widzenia zasad tłumaczenia literatury pięknej tłumaczka nie musiała stosować transliteracji w odniesieniu do danej abrewiatury. Ze względu na skojarzenia z polskim leksemem mur wyrażenie ,pracował w wydziale MUR-u” nie wydaje się wystarczająco informatywne. Trudno też w tym wypadku mówić o zachowaniu kolorytu przez zastosowanie realiów, nie jest to bowiem słowo nacechowane kulturowo. Użycie prawidłowego ekwiwalentu pozwoliłoby uniknąć konieczności wprowadzania przypisu objaśniającego realia.

Abrewiatury pojawiają się $\mathrm{w}$ tekstach tłumaczeń powieści Marininy często $\mathrm{i}$ ich wprowadzenie powoduje zwykle zaburzenie recepcji powieści, na przykład Byłam kierownikiem GUWD Moskwy (Kolacja z zabójca, s. 61). ГУВД to Главное управление внутренних дел Москвы. Bartosik nie rozszyfrowuje tu znaczenia tej abrewiatury, sądząc zapewne, że czytelnikowi wystarczy komentarz zamieszczony stronę wcześniej. РУВД, czyli Районное управление внутренних дел, zostało przethumaczone jako Rejonowy Oddziat Spraw Wewnętrznych, zamiast - wydział, jeśli taką strategię przyjęła tłumaczka. Należy jednak zauważyć, że termin Управление внутренних дел $\mathrm{w}$ takiej formie, jak przedstawiono to na kartach powieści, wywołuje asocjacje z Ministerstwem Spraw Wewnętrznych, nie zaś $\mathrm{z}$ jednostką organizacyjną milicji. $\mathrm{W}$ istocie bowiem, mając na celu stworzenie ekwiwalentu funkcjonalnego, należałoby mówić o komendzie rejonowej milicji. Problemy z rozszyfrowaniem abrewiatur mają też inne tłumaczki. Ewa Rojewska-Olejarczyk tłumaczy ГУВД jako wydziat spraw kryminalnych, mimo że chodzi o Komendę Główną Milicji. Jest to organ terytorialny władzy wykonawczej, który wchodzi w skład systemu organów spraw wewnętrznych, a nie jeden z wydziałów:

Однако, положив трубку, она тут же вспомнила, что звонок на самом деле был, да еще из ГУВД. (Игра на чужом поле ${ }^{13}$, s. 35)

Jednak zaraz po odłożeniu stuchawki urzędniczka przypomniała sobie, że telefon byt naprawdę, a w dodatku $z$ wydzialu spraw kryminalnych. (Gra na cudzym boisku ${ }^{14}$, s. 28)

Ta sama tłumaczka na następnej stronie popełnia kolejny błąd: городское управление („urząd miejski, ratusz”) thumaczy jako miejski urząd spraw wewnętrznych:

13 A. Marinina, Igra na čužom pole, Moskva 1993.

${ }^{14}$ A. Marinina, Gra na cudzym boisku, przeł. E. Rojewska-Olejarczuk, Warszawa 2005. 
На всякий случай администратор решила подстраховаться и ссылаться на звонок не из городского управления, а из МВД России. (s. 36)

Recepcjonistka postanowiła się na wszelki wypadek zaasekurować i powolywać w razie czego na telefon nie z miejskiego urzędu spraw wewnętrznych, ale z samego MSW. (s. 29)

W wielu przypadkach spotykamy błędy terminologiczne, które są konsekwencją nieznajomości prawa. Obserwujemy to na przykład w przekładzie leksemów следователь и сыщиик, które tłumaczki przekładają najczęściej (nie zawsze jednak konsekwentnie) za pomocą jednego odpowiednika — śledczy, podczas gdy ekwiwalentem funkcjonalnym dla pierwszego z nich jest dochodzeniowiec, dla drugiego zaś detektyw lub pracownik operacyjny.

Я бывший следователь. (Стечение обстоятельств, s. 56)

Sama byłam kiedyś śledczym. (Kolacja z zabójca, s. 49)

Termin подследственный tłumaczony jest jako podejrzany zamiast osoba podejrzana. Przypomnijmy, że polska procedura karna wprowadziła rozróżnienie pojęć podejrzanego i osoby podejrzanej. Najprościej rzecz ujmując, osobie podejrzanej nie nadano jeszcze formalnie statusu podejrzanego ani oskarżonego, podejrzany zaś to ktoś, komu przedstawiono już zarzuty:

Назову фамилии следователей, которые прекращали с вамего благословения уголовные дела по липовым справочкам о неизлечимом заболевании подследственного. (Стечение обстоятельств, s. 105)

Mogę podać nazwiska śledczych, którzy zamykali sprawy za pańska zgodą na podstawie zaświadczeń o nieuleczalnej chorobie podejrzanego. (Kolacja z zabójca, s. 90)

W innym miejscu tłumaczka nie zachowuje nawet konsekwencji w stosowaniu przyjętego przez siebie ekwiwalentu.

А в карточках есть и фамилиия следователя, и фамилия подследственного. (s. 104)

A w kartach figuruja nazwiska śledczego i oskarżonego. (s. 91)

Tłumaczki mają problem nawet z prawidłowym nazwaniem zawodu głównej bohaterki. Aleksandra Marinina wykreowała ją jako genialnego analityka, czyli osobę, do której należy praca polegająca na analizie zebranego materiału dowodowego. Rojewska-Olejarczyk pisze natomiast, że jest ona „starszym oficerem operacyjnym”, co stoi w sprzeczności z zamiarem autorki. Przymiotnik ,operacyjny” jest bowiem stosowany w odniesieniu do pracowników zatrudnionych w terenie.

Да-да, давайте назвать вещи своими именами, она совершила уголовно наказуемое деяние. И что? Стылно ей? Да ни капельки. Только очень противно. Ей, Анастасии Каменской, старшему уполномоченному уголовного розыска, юристу с высшим образованием, майору милиции, нисколько не стыдно перед собой. (Игра на чужом поле, s. 17)

Wczoraj dała łapówkę. Tak, tak, nazywajmy rzeczy po imieniu, dokonała czynu karalnego. I co? Czy jest jej wstyd? Ani trochę. Czuje tylko niesmak. Anastazja Kamieńska, starszy 
oficer operacyjny milicji kryminalnej, magister prawa, major, wcale się tego nie wstydzi. (Gra na cudzym boisku, s. 14)

W Kolacji z zabójca Bartosik zawieszone postępowanie (присотановленное производство, s. 96) thumaczy jako wstrzymane postępowanie (s. 83).

Ze względu na ograniczenia formalne nie jest możliwe omówienie nawet niewielkiej części błędów tego typu. Są to błędy terminologiczne, które wynikają z niedostatecznej wiedzy specjalistycznej tłumaczek, choć wiele jest przykładów błędów elementarnych. Razi to zwłaszcza dlatego, że te uchybienia można było łatwo zweryfikować, jeżeli tylko thumaczki wykazałyby taką wolę. A tej najwyraźniej zabrakło. Można to też odczytać jako wyraz pewnego lekceważenia czytelnika.

Przebadany materiał egzemplifikacyjny wskazuje na podstawowe problemy wszystkich tłumaczek. Należy do nich na przykład nierozpoznanie terminów w tekście i, co się z tym wiąże, niekonsekwencja w ich stosowaniu w charakterze ekwiwalentów. Przypomnę, że za główną cechę terminów uznaje się zwykle ich jednoznaczność w granicach określonej dyscypliny, to jest odniesienie do jednego pojęcia lub denotatu. Rozpoznanie terminu w tekście, umiejętność odróżnienia go od quasi-homonimicznych elementów dyscyplin pokrewnych stanowi, moim zdaniem, istotę praktyki tłumaczeniowej. Odnosi się to zarówno do thumaczy specjalistycznych, jak i tłumaczy tekstów literackich. Tłumacz musi zrozumieć tekst wyjściowy, wykorzystując do tego wszystkie dostępne mu kompetencje, następnie zaś podjąć takie decyzje przekładowe, aby odbiorca prawidłowo zinterpretował tekst docelowy. Brak określonych kompetencji (lub niedostateczne przełożenie posiadanych kompetencji na wykonanie zadania) może zostać wychwycony przez odbiorcę docelowego, którego wiedza i kompetencje przewyższają te, jakimi dysponuje thumacz. Prowadzi to do zaburzenia przebiegu komunikacji.

Analizowany materiał daje też możliwość wskazania na kilka innych kwestii — na brak „czystości” gatunkowej powieści Aleksandry Marininy (co świadczy raczej na ich korzyść) oraz na wynikające stąd implikacje dla thumacza. Zmącenie gatunku powoduje, że thumacz stoi przed koniecznością nieustannego śledzenia za poszczególnymi rejestrami komunikacyjnymi. Główna bohaterka to nie tylko milicyjny analityk, lecz także matematyk i poliglotka. Ta wieloaspektowa możliwość odczytania jej postaci przekłada się na język i styl powieści. Jest to wyzwanie, którym thumaczki rzadko potrafią sprostać.

Pojawia się tu też kwestia przygotowania specjalistycznego thumacza. Z jednej strony mamy niewątpliwie do czynienia $z$ tekstem, który nie ma parametrów tekstu specjalistycznego; z drugiej jednak - specjalistą jest i autorka, i wykreowana przez nią bohaterka. Czytelnik przekładu ma prawo oczekiwać, że język i styl thumaczeń, które dostaje do ręki, będą to odzwierciedlać. Praca nad przekładem tego typu tekstów wymaga więc pogłębionej analizy przedtłumaczeniowej, pozwalającej na wykrycie specyfiki dyskursu, przygotowania strategii komunikacyjnych i optymizację tekstu przekładu. Strategia przekładu równoznacznego 
pod względem komunikacyjnym zakłada przecież realizację intencji komunikacyjnej autora oryginału $\mathrm{w}$ postaci stworzenia tekstu $\mathrm{w}$ innym języku, mogącego oddziaływać na czytelnika przekładu zgodnie z oczekiwaniami autora oryginału. Zadaniem dobrego thumacza jest właściwe odczytanie konwencji (również stylistycznej) i odpowiednie jej zrekonstruowanie w języku docelowym. Wystąpienie w danym tekście polifonii (jeśli chodzi o nasycenie tekstu językiem specjalistycznym) należy zaliczyć do komplikacji wewnątrztekstowych. Tłumacz zobowiązany jest jednak do przekazania całej warstwy znaczeniowej utworu.

Nie było moim celem jedynie wskazywanie na błędy tłumaczek. Ważne natomiast było pokazanie skutków, jakie niesie z sobą niekompetentne (źle wykonane) thumaczenie. Jeżeli thumacz nie jest specjalistą, powinien być przygotowany na uzupełnienie wiedzy w niezbędnym mu zakresie. Wymienione wcześniej kompetencje nie zawierają tego istotnego elementu, który polega na zdobywaniu wiedzy niezbędnej do przetłumaczenia danego tekstu. Trudno bowiem oczekiwać, że kompetencja encyklopedyczna (nieuzupełniana na bieżąco) będzie wystarczająca w odniesieniu do każdego tekstu, który tłumaczowi przyjdzie tłumaczyć. Dzięki przytoczonym przykładom widać wyraźnie, że musi ona być wciąż rozbudowywana, thumacz zaś powinien mieć świadomość swoich braków. Ta świadomość powinna mu zasygnalizować, że nawet za komunikatem, który wydaje mu się zrozumiały, może stać coś, co wymaga sprawdzenia. Taka właśnie umiejętność wydaje się niezbędna w wypadku tekstów, w których pojawia się leksyka specjalistyczna $\mathrm{z}$ jakiejkolwiek dziedziny. Umiejętność taką można potraktować jako oddzielną kompetencję badawczą. Wskazuje ona być może na konieczność rewizji dotychczasowego podejścia do kompetencji tłumacza.

\section{Bibliografia}

Albin J., Kompetencja z punktu widzenia thumacza, [w:] Kompetencje thumacza, red. M. Piotrowska, A. Czesak, A. Gomola, S. Tyupa, Kraków 2012.

Balcerzan E., Literatura z literatury (strategie tlumaczy), Katowice 1998.

Czubaj M., Etnolog w mieście grzechu. Powieść kryminalna jako świadectwo antropologiczne, Gdańsk 2010.

Dąmbska-Prokop U., Kompetencje tlumacza, [w:] Mała encyklopedia przekładoznawstwa, red. U. Dąmbska-Prokop, Częstochowa 2000.

Dzierżanowska H., Przekład tekstów nieliterackich na przykładzie języka angielskiego, Warszawa 1990.

Grucza F., Lingwistyka, lingwistyka stosowana, glottodydaktyka, translatoryka, Poznań 1996.

Grucza F., Lingwistyka, lingwistyka stosowana, glottodydaktyka, translatoryka, [w:] Lingwistyka, glottodydaktyka, translatoryka, red. F. Grucza, Warszawa 1985.

Grucza F., Zagadnienia translatoryki, [w:] Glottodydaktyka a translatoryka, red. F. Grucza, Warszawa 1981.

Marinina A., Gra na cudzym boisku, przeł. E. Rojewska-Olejarczuk, Warszawa 2005.

Marinina A., Igra na čužom pole, Moskva 1993.

Marinina A., Kolacja z zabójca, przeł. M. Bartosik, Warszawa 2010.

Marinina A., Stečenie obstoâtel'stv, Moskva 1993.

Slavica Wratislaviensia 171,2020

(C) for this edition by CNS 
Piotrowska M., Proces decyzyjny thumacza. Podstawy metodologii nauczania przekładu pisemnego, Kraków 2007.

Pisarska A., Tomaszkiewicz T., Współczesne tendencje przekładoznawcze, Poznań 1996.

\section{Specialised lexis in a literary text and translator's competences (based on Polish translations of Russian crime novels by Alexandra Marinina)}

\section{Summary}

The article focuses on translator's competences seen as a "product" created as a result of his/ her activity. Competence assessment concerns specific components of the translator's knowledge which, among others, include: knowledge of the subject matter presented in the translated work, general knowledge of the world, specialised knowledge as well as particular skills such as, for example, professional recoding of the message. The study is based on an analysis of translations of Alexandra Marinina's crime novels.

Keywords: translation, competence, translator's knowledge, crime novels

\section{Специальная лексика в литературном тексте (на материале польских переводов детективных романов Александры Марининой)}

\section{Резюме}

В настоящей статье предметом нашего интереса является компетенция переводчика, воспринимаемая в контексте оценки текста, который является результатом его переводческой деятельности. Эта оценка касается компонентов переводческих знаний, в частности знаний о предмете перевода, а также энциклопедических и специальных знаний. Помимо прочего, учитываются здесь конкретные умения, такие как возможность профессионально передать сообщение с помощью определенного кода. В качестве материала для анализа были использованы польские переводы детективных романов Александры Марининой.

Ключевые слова: перевод, компетенция, переводческие знания, детективные романы

Slavica Wratislaviensia 171, 2020

(C) for this edition by CNS 